Vol. 8(7), pp. 88-97, October, 2016

DOI: $10.5897 / J A S D 2016.0415$

Article Number: 5FOOF9B61112

ISSN $2141-2189$

Copyright (c) 2016

Author(s) retain the copyright of this article

http://www.academicjournlas.org/JASD

Review

\title{
Killing Ebola: The militarization of US aid in Liberia
}

\begin{abstract}
Drew Alexander Calcagno
School of Oriental and African Studies (SOAS) at the University of London, London WCH1 0XG, United Kingdom.

Received 6 September, 2016; Accepted 11 October, 2016

In Liberia, the security-development nexus strongly emphasized the security side when Ebola became an international crisis with potential for global risk in 2014. In West Africa, 28,600 people had contracted Ebola and over 11,300 of them died. Liberia was the hardest hit with death from the disease, killing over 4,800 people. Similar to other interventions after $9 / 11$, the US response to Ebola was intended to be a whole-of-government approach. Nevertheless, its implementation was forged predominantly by the US President's command that several thousand troops would be deployed. This piece, through an analysis of primary interviews; oral histories of diplomats, military officers, aid workers, doctors, and Ebola treatment personnel; official documents; and other scholarly work undertakes an examination of the effects of the US' militarized response. The article reveals the disconnect between the construction and health needs of Liberians afflicted with Ebola and the deployment of US combat-oriented troops. In doing so, this article challenges assumptions of the role of the US military in humanitarian crises, as well as the efficacy of aid in the midst of the Ebola outbreak.
\end{abstract}

Key words: Ebola, Liberia, US, militarization, aid, security.

\section{INTRODUCTION}

In 2014, Liberia endured the worst epidemic of an Ebola virus strain in human history (Chan, 2014). Nearly 30,000 people contracted the disease in West Africa and Liberians living in the capital suffered a rate of nearcertain death with a survival rate of only six percent at its worst points (WHO, 2016; UNMIL Official 1, 2016). Driving to work in an embassy or walking to a local church could mean passing dead bodies on the roadside. As a result of this local-turned-global epidemic, the international community and the Liberian government worked together to eradicate the disease. This article will consider the US response to the Ebola crisis through a lens of militarization of aid. It draws upon experience of numerous actors in the Ebola crisis, involving primary interviews; oral histories of diplomats, military officers, aid workers, doctors, and Ebola treatment personnel; and official documents. The US was the most prominent actor in the Ebola crisis response in Liberia and did so through a collaborative effort across many agencies in the US foreign affairs apparatus. Nevertheless, arguably the main actor in that system was the US military. With an existing security sector reform (SSR) mission called Operation Onward Liberty (OOL) and an Ebola crisis response mission called Operation United Assistance

E-mail: 633127@soas.ac.uk.

Authors agree that this article remain permanently open access under the terms of the Creative Commons Attribution License 4.0 International License 
(OUA), the US' breadth of operations was vast.

The predominant concern was to build Ebola Treatment Units (ETUs) which are field hospitals for Ebola patients. In order to complete this mission, the OUA consisted largely of the 101st Airborne Division (101st) -a storied Army combat unit. This article attributes the US reaction to fearful paranoia and pressure to institute a response, which resulted in sending a combat unit for a construction and health mission, as well the consequences of that decision for Americans, Liberians, and the future nations of US intervention. The piece delves into the development of a securitized culture in Liberia from the viewpoint of US partnership through its modern history and explores the intricacies of the US response during the Ebola crisis. Second, the article presents the cultural and logistical differences between ETU operations of the US and of other providers, particularly Médecins Sans Frontières (MSF). Third, it contrasts the conduct and consequences of the US intervention in Liberia with that of other recent interventions in Afghanistan and Iraq. The piece concludes with a discussion of the US trend of militarization of aid and the consequences of the Ebola response on future US conduct abroad.

\section{A militarization of aid framework}

A militarization of aid theoretical framework assumes a multitude of forms throughout the post-9/11 era. I chose predominantly to build off Krahenbuhl's (2011), definition of militarization of aid as the use of armed forces in humanitarian activities. He considers this to be the "blurring of lines" debate. This article adds an analysis of how the militarization of aid throughout the US-Liberian historical relationship created a culture of acceptability of securitization during the 2014 Ebola crisis. With Krahenbuhl's framework in mind, here, I utilize "securitization" to mean the increase of armed forces in a space which results in military dominance and a weakening of humanitarian institutions' agency. Combined with the US aid militarization trends of the post-9/11 era, particularly in the Afghan and Iraqi intrusions, this article will explore how this acceptability of securitization pervaded a wide breadth of missions, not just ones inherently combative, and how that securitization affected taxpayer cost, local trust, and health outcomes. This section will explore those post-9/11 trends from which the rest of the piece will draw upon for comparison and critique.

Conversely, and not unlike an on-going health response, peacekeeping theoretical frameworks are few and far between. "Much of the writing on the subject has been done by diplomats and military people with experience in the field. This has tended to limit the accumulation of knowledge on peacekeeping as an intervention to case histories interesting, often, in themselves, but with little generalizable value beyond a tentative list of do's and don'ts" (Fetherston, 2000: 191). US aid in Liberia involved both peacekeeping with $\mathrm{OOL}$ and the Ebola health response with OUA. Likewise, "the standard study of peacekeeping remains one of a single case study, in which description is the primary goal... An approach based on the uniqueness of peacekeeping missions does not assist us in building a theory of peacekeeping, nor does it provide much guidance in making policy" (Diehl et al., 1998: 34; Fetherston, 2000: 191). The argument here expands beyond Diehl et al. and Fetherston's charges by extending the description of the single-case design of the US response in the Ebola crisis to a greater analysis of US-Liberian securitization histories as well as post-9/11 militarization of aid trends to which the militarization in the 2014 Ebola crisis becomes a logical summation in the framework.

Most of the literature concerned with militarization of aid suggests that the blurring of lines between combatoriented military activities and humanitarian-oriented military activities creates danger for humanitarian organizations and creates a paradigm of implicit consent for their mutual existence in a space. While armed conflict was not a concern during the Ebola crisis, the implications for future relations between the military, humanitarian organizations, and local communities depend on the trends made both in and out of formal wartime. Collier and Hoeffler (2002), consider a positive outcome where military aid tends to increase capability to deter spoilers from entering violent conflict. Kim and Nunnenkamp (2013), also empirically acknowledge that US-based NGOs found greater access to funding when they were operating in the vicinity of military counterparts. On the other hand, much of the literature considers the alternative, more negative, view. Dube and Naidu (2014), conclude that conflict tends to increase after an influx of US military aid (2014). Accounting for endogeneity, they found that Latin American paramilitary attacks increased during the years of most US military aid. Krahenbuhl asserts that humanitarian organizations are in greater danger when military forces are present, even if the latter aims to have synergistic effects with the population (2011). He does so with an understanding of how many in the field can be hypocritical in framing requests and rejections of security that come with military presence. "This is not the only way to engage in humanitarian action but aid agencies cannot have it both ways: asking for armed escorts to reach populations in need one day and criticizing those same military forces for blurring the lines the next cannot be a solution. ... Humanitarians cannot simply point fingers and exclude their own choices and actions" (Ibid., : 1). David Mitchell nuances that assertion with a panel-corrected standard error regression model, proving that security incidents during the US intervention in Afghanistan increased for NGOs in military vicinity only in provinces where military action was lead by an entity 
other than Americans. Thus, Mitchell (2015), concluded that uniquely US securitization may not deserve the charges placed on all aid militarization and its potential negative effects on NGO survivability.

However, as much as Krahenbuhl warned of the challenges of humanitarian organizations desiring security and capacity from the military, the trend of securitization in Liberia continued in the face of requests for it. The head of MSF, Joanne Liu, one of the grittier and staunchly non-military actors in the crisis called for military intervention due to the severity of the disease in the late summer months of 2014. Yet the American way did not reflect her intentions of the call to action and she reacted with exasperation when she found out that US troops would be deployed with the direct mandate not to interface with actual Ebola treatment. "Countries are approaching [the military intervention] with the mindset of going to war,' she says. 'Zero risk. Zero casualties'" (Arie, 2014: 1). The head of MSF attempted to consider the military response in its own jargon calling "current military efforts as the equivalent, in public health terms, of airstrikes without boots on the ground... 'You need to send people not stuff and get hands on, not try to do this remotely"' (Ibid.). Others have criticized the risk-averse trend with relation to cost to the taxpayer. "The problem with the military is that a treatment center [ 50 beds] may cost $€ 7 \mathrm{~m}[£ 5.5 \mathrm{~m} ; \$ 9 \mathrm{~m}]$ over one year. But if it's done by the US military, it's going to cost $€ 70 \mathrm{~m}$, because they are going to come with their own bubble so they won't get sick" (Ibid., :2). Nevertheless, something had to be done and thus began the debate - or lack thereof due to hasty timing of how to do 'it' with the definition left up to the provider.

Timing became another concern, as well as how that timing related to relative expertise in terms of health systems and contagious diseases. "When you look at the figures in absolute [compared with other diseases that kill many more people] people say 'why are we getting so excited?' But Ebola has completely killed the infrastructure of these countries. It is attacking the state and the health structures" (Ibid., :2). Thus, searching for quick-fixes, overwhelming creation of safety for the health and military providers, and exorbitant costs all became commonplace.

\section{The US in Liberia during the Ebola crisis}

Liberia's special relationship with the US runs strongly along quasi-colonial lines despite not having its neighboring countries' bona fide colonial ties, such as Sierra Leone with the UK or Guinea with France. Global conflict tended to join the two, particularly in World War II with rubber extraction and in the Cold War with Liberian President Samuel Doe's willingness to expel Soviet and Libyan influence (PBS, 2002). More recently, the US has all but designed the Armed Forces of Liberia (AFL) (George, 2016) and has maintained a robust diplomatic post in Monrovia. Once Ebola became a serious concern, that relationship was renewed. In December 2013, an infant named Emile Ouamouno became the first recorded case of Ebola. Ouamouno likely contracted the Zaire Ebola virus strain from a bat, and passed it through his village, Meliandou, in the forested region of southeast Guinea (Leach, 2015). "The mysterious fever spread to his family members, to an under-equipped rural health center, and then through a health worker' s funeral, and related kin and trading networks, to others, in this region of high mobility and sociability...By the time the international community belatedly responded, the epidemic was already out of control" (lbid., :817-818). By the time the World Health Organization (WHO) released a statement of this 'patient zero,' due to an acknowledged underwhelming response, months had passed. Lack of functional laboratories to diagnose and few regional doctors to treat also contributed to the exponential number of cases (WHO, 2014; Parham and Wanjue, 2016; Mitchell, 2016). As a result of the August declaration, the months that had passed proved to be the worst ones, partially because of the WHO's delay in labeling the Ebola crisis as an emergency of international concern, "a legal mechanism that flips switches in the international community so that funding and expertise are mobilized faster and protection measures are put in place" (Arie, 2014: 2).

Regardless of fault, the local community as well as the international community was caught off guard with the exponential growth across the region, hitting Guinea, Sierra Leone, and Liberia the hardest. It was later estimated that by the time the region was declared Ebola free, over 28,600 people had contracted Ebola and over 11,300 of them died. While more cases showed up in Sierra Leone, Liberia was hardest hit with death from the disease over 4,800 people died (WHO, 2016). Before those figures were established and Ebola subsided, the US government and other organizations formed a complex machine of responses in the midst of pressure to act quickly, combined with a presence of confusing misinformation. For the purposes of this article, the 'Ebola crisis' will be generally referred to as year of 2014 in which the epidemic was most active. Nevertheless, the full range of time when Ebola was present was much larger. There were pre-existing health conditions which set the stage for the crisis as early as 2013 , leading to the first confirmed case in December of that year. The disease pervaded in small forms until January, 2016 when Liberia and the greater region were declared Ebolafree. Liberia was declared Ebola-free in May, 2015, but there were subsequent minor flare ups and two 21-day incubation periods had to pass without a case in order to issue another declaration (WHO, 2016b).

The US has an ongoing SSR operation, OOL, which 
aimed to be an advisory mission for post-civil war Liberia security sector. Since 2010, the US has deployed Marines and national guardsmen to live in the AFL barracks and work with the Liberian military on establishing best professional practices in their role (Rankin, 2015; Selbach-Allen, 2016). In comparison to the UN Mission in Liberia (UNMIL), this operation is quite small yet it has an enduring relationship which came with benefits such as extensive latitude and trust between the organizations. Not only does the AFL trust the OOL personnel, so does the US military leadership something that proved to be significant in relation to the restrictions placed upon the Ebola response mission, OUA, which had paralyzing regulations at its inception in late 2014 (Paskman, 2016; Potter, 2016). Initially when Ebola reports came in to the White House, the President and Defense officials decided upon a modest response a 25bed field hospital for patient treatment. This announcement came on the September 12th, 2014 (Cronk, 2014). In very short order, there was outcry across various sectors, including the development community, accusing the US of shirking responsibility in the crisis most notably Liberian president Ellen Johnson Sirleaf (Cooper et al., 2014).

As a result of that outcry, the US ramped up its stance on how it would assist the response, despite the fact that "top White House aides... rejected criticism from African officials, doctors and representatives from aid groups who said the United States had been slow to act in the face of the disease... [explaining that the US] had committed more than $\$ 100$ million since the outbreak started in the early spring" (Cooper et al., 2014: 3). Thus, OUA was created when National Security Council (NSC) advisors presumably promoted a military response to the President. President Obama announced that 3,000 troops would deploy to the region on September 16th, 2014 (Lane and McNair, 2015). When the announcement was made in September, the crisis was at its peak, but when OUA arrived a month later, the worst bit of the crisis had passed. Nevertheless, the analysis of the level of decline was only possible in hindsight, as those on the ground were unable to accurately assess the significance of the decline until later that year (Selbach-Allen, 2016b). Troops were not necessary in that high amount of the originally stated 3,000 . Nevertheless, the 101st was tasked to fill the job.

Not only was the choice of a military response a surprise to many on the ground, even the pre-existing military officers in-country, the 101st proved to be a curious choice most likely due to which units were available and ready to deploy rather than the thematic skillset they provide and capabilities needed for constructing a response to a disease rather than warring factions (Lane and McNair, 2015; Selbach-Allen, 2016). However, that choice was one that largely escaped criticism, save some officers in the Army as well as in the
Marine Corps. US Army Captains Lane and McNair look with a skeptical eye in the midst of this choice to send the military, particularly a combat unit. "As a nation, it is important to discuss the role of military personnel in response to a disease outbreak and address the ethical issues surrounding their participation" (Lane and McNair, 2015: 607). The potentially erroneous choice to send in a combat-oriented unit instead of a construction and healthoriented unit did not come without better-suited alternatives. While choices in deployment at strategic levels are constantly held under the pressure of readiness and availability, there are units for the many events along the spectrum. For instance, the Army and Navy both have their own construction forces. Naval construction forces, known as 'Seabees,' make up a truly significant portion of US military forces in Africa, particularly those running out of East Africa via the only major US military base on the continent, Djibouti's Camp Lemonier. Their extensive projects assist local forces and construction projects year-round, building roads, bridges, buildings, and other structures (Gibson, 2013). In their defense, some Seabees were sent to assist the OUA mission in September of 2014, although rather than making up a majority of the planned 3,000 troops, they made up a half of a percent: only 15 personnel (White, 2014). Despite the fact that the Seabee's charter would have them as the best fit for the Ebola response mission of building structures, very few interviewees mentioned their contribution mostly likely due to their small numbers.

In addition to the Seabee's contribution with site visits to determine how and where to build ETUs originally with the goal of constructing one in every county of the country some worked with the original Disaster Assistance Response Team (DART), one of the very first groups to arrive in-country and assess how to lead the response (White, 2014). DART, a small coalition of handpicked experts from government agencies like the US Center for Disease Control (CDC), the US Public Health Service, and the aforementioned US military, is lead by USAID's Office of Foreign Disaster Assistance (OFDA) (USAID, 2016; Parham and Wanjue, 2016). Despite the expertise in the DART, several officials stated that their best intentions were met with a difficult environment, one that was in the middle of a crisis that seemed to be getting worse. Unlike other DART excursions after earthquakes in Haiti or tsunamis in Indonesia, this team was plunged into a health crisis unlike any other the organization had ever faced, making their response very difficult to lead. As a result of the little mention of Seabees or other military construction forces during an inherently construction-oriented mission to build ETUs, the apparent lack of communication on behalf of the NSC with those on the ground and the combatant commands, US deployed the 101st in hopes of controlling the environment. There has been a lack of analysis on behalf of why this unit was involved instead of more 
capacity-oriented units such as the construction forces mentioned in the previous discussion of the Seabees. Some Army officers contend, "Part of the lack of discourse certainly stems from a reluctance to address the role and ethics of military involvement in the medical literature or the media - particularly when the mission seems noble and justified" (Lane and McNair, 2015: 607).

In order to deploy the 101st and the associated advance teams as well as pay for the construction of ETUs - the main goal of the mission it cost the DoD over $\$ 330$ million as of March, 2015. This does not include the additional $\$ 72$ million on the actual disease: $\$ 25$ million on vaccine research and $\$ 47$ million on biosurveillance and biosecurity, making up 'cooperative threat reduction' (DoD, 2015). One may see that the most 'effective' logistical force in America's arsenal for disaster response is also an expensive one. Furthermore, USAID/OFDA spent over $\$ 510$ million in response to Ebola in Liberia alone (USAID, 2016). Thus, US taxpayers as well as Liberian government and society ought to consider the price at which deploying the military costs. This is especially important when units are sent on a basis of readiness rather than capacity (that is, sending the 101st rather than purely mission-specific personnel like the Seabees). Otherwise, bottom lines of stopping the spread of Ebola may take advantage of undue fear (often at the fault of sensational media) and exorbitant death rates (much due to poor hygiene practices and lack of/rejection of simple care, rather than the actual deadliness of the disease). Acting on that fear may produce a paradigm that necessitates quick, nervous action rather than calculated, contextually-sufficient response. The US also played a serious role in international leadership to keep the region's civil and commercial society running in the midst of paranoia.

Many Troop Contributing Countries (TCCs) wished to leave UNMIL during the outbreak, but none ended up retreating much due to the US' example of keeping their operations open through the crisis (Mitchell, 2016). Through various liaison efforts and trust-building conversations, the US government convinced civilian airlines to continue running routes to Monrovia, which consequently allowed for evacuations and disaster-relief personnel's entry and exit. This was predominantly completed by Brussels Airlines, which agreed to continue flights under the condition that their pilots would not have to stay in Monrovia. The US government was able to gain trust of the nearby Senegalese government to allow Liberian flights to route to Senegal for the Brussels Airlines pilots to get rest and keep the operations running (Ibid.). This type of unconventional leadership outside the purview of typical Ebola-related activities proved to be imperative for the collective effort throughout the region. While the US' efforts were monumental to the crisis response, numerous countries' governments and NGOs spent valuable resources to end the fear and death surrounding Ebola. MSF proved to be one of the most consequential organizations due to their extensive work with treating Ebola patients. The largest ETUs were run by MSF and they incorporated foreign as well as local treatment workers they accepted all patients as well. In the midst of horrifying death rates, upwards of $94 \%$, it was MSF's ETUs that bore the brunt of the care requirements during the height of the outbreak in mid2014 (Barclay, 2016; UNMIL Official 2, 2016). The German military also provided a security presence for the environment and the Chinese government built ETUs across the country (UNMIL Official 1, 2016). As a result, the US was not the only entity which militarized its aid in response to Ebola. China focused its efforts and funding on its People's Liberation Army (PLA) medical branch and earned domestic criticism for it, with scholars suggesting that more thought ought to have been given to the strategy of intervention and the selection of nonmilitary units. In the future, some argue that "more thinking from the epidemiology, translational medicine, and sociology aspects of the outbreak will help to formulate the 'go global strategies' of PLA and our medical service" (Cheng-zhong, 2015: 581). Thus, the notion that a nation must act quickly has been critiqued in favor of more contemplative action by both sides of foreign development actors, the US and China.

\section{Approaches to Ebola treatment units: US VS MSF and others}

The construction of ETUs and the nature of heath workers' personal protective equipment presented an acute problem for many Liberians, it rang not only of otherness but also of the extractive trade industries of the country's and greater region's history (Leach, 2015). Ebola treatment began to epitomize the difference of the developers and the to-be-developed and it was "magnified by spacesuit-like protective suits [which] have been interpreted as extractors of human resources body parts, blood and lives to serve mysterious but assumedpowerful international markets" (Ibid., :821). In response, some healthcare workers and journalists were deliberately killed by local communities (Phillip, 2014) and others refused doctors' care even just food and water (Barclay, 2016) out of fear that the foreign actors were sent to do harm rather than supply beneficial and possibly lifesaving treatment. Josephine Barclay, a Liberian school psycho-social counselor joined MSF's call for local residents to be trained and work inside the Eternal Love Winning Africa (ELWA) ETU, a location in Monrovia which became the world's largest ETU. Barclay explained that Ebola was killing so many people not so much because of its deadly qualities, but rather because of lack of empathy from the ill's communities and caretakers. The social stigma of having the disease was so strong 
that many Ebola patients believed that they no longer had worth in society something that their communities' fear reinforced and that they deserved to die. Many in ELWA would stop taking rehydration treatments and hide their painkillers to make it look like they had taken the medication when in fact they were unduly suffering.

Barclay was able to turn the tide for her patients by demonstrating a linkage between her experience and their sickness. She had previously suffered a major burn in a cooking fire which resulted in social stigmatization due to the aesthetic damage. After explaining her own physical and emotional recovery to her patients, as well as demonstrating how the food, water, and medication were not provided by white foreigners paid to kill the patients, she found that the empathetic approach yielded near unanimous change in the patients' attitudes towards treatment. While not all ETU workers had the same compelling background ripe for empathetic communication with the sick, many culturally-sensitive and local approaches proved to make more of a difference in slowing the spread of the disease (Spearie, 2016; Vrey, 2016; UNMIL Official 1, 2016; George, 2016; Gaye and Hector, 2014). Without appearing trite, Barclay described how altering the atmosphere was imperative to disrupt the macabre ETU environment. She embraced dancing with the patients to assess their mental health for acute stress disorder (Barclay, 2016). Others took a similar approach to resonate with the mind-body connection. "We share jokes and we laugh. And the patients, because I feel like that could be me or my relatives inside there. If I don't come to tend to that person, who will? If everybody is afraid to enter the Ebola unit, who will go? Nobody. And our Liberian sisters and brothers will die" (Gaye and Hector, 2014: 1). Rather than one-off approach to make Ebola patients feel better, local measures and Liberian-Liberian care became the cornerstones of the nation's recovery from a disease that had upwards of a $94 \%$ death rate at its height in the capital (UNMIL Official 2, 2016).

By the time the US began to build ETUs in late 2014, ELWA and other ETUs had borne the brunt of patient treatment services and the full planned response of constructing and US-led ETU in every province was no longer necessary (T. Mitchell, 2016). Instead, OUA focused on constructing ETUs for healthcare workers in order to avoid a lapse in health leadership elsewhere. Nevertheless, the choice for who could and could not be admitted to the US ETUs was decided upon not only by US forces but predominantly the Liberian Public Health Service via the Incident Management System (Chamberlain, 2016). However, this selection process and the mandate for healthcare-workers-only was not always clear for others on the ground, even those working at other ETUs. While not intended, there was potential for exclusionary care, especially when it appeared that "it seemed to take only two weeks for patients in the US ETUs to get better, and in MSF tents it took more like six weeks," partly due to better resources and plentiful bed space (Barclay, 2016). This comparison also revealed that MSF endured the crisis longer than other organizations, including the US military. And yet, MSF was able in-part to endure due to the US ETUs providing care to infected MSF staff (Ibid.). While relationship proved to be symbiotic, Disaster Risk Reduction (DRR) scholars warn that one of the most important principles of care is that investment must not privilege one group over another, or "exclude the very people who are at the greatest risk" (Hewitt, 2016), which became the case for those confronted with the notion that US ETUs only treated healthcare workers, not the majority of Liberian Ebola victims.

\section{US Interventions: Contrasts between Liberia, Afghanistan, and Iraq}

The reception of the US government in Liberia is a curious departure from a skeptical narrative as was exemplified in the US intervention in Afghanistan (Christie, 2012). Liberians tend toward an acceptance of the US government in its ubiquity, particularly the presence of the military (Chamberlain, 2016). This departure runs in utter contrast to the Provincial Reconstruction Teams' (PRTs) experience with Afghani's mixed trust, and often distrust, of those in uniform performing activities outside of typical violent combat. While the United States and Liberia do not have colonial ties, the latter nation's history was born by the former. The Liberian state was 'created' by freed US slaves, sent 'back to Africa' by US colonization societies and encouraged to have autonomy over their new, albeit inhospitable, land in the mid 1800s (Ciment, 2013). Surprisingly, this recipe for hatred and bad blood paradoxically transpired into what many considered a love. There is potential for bias in what the interviewees explained, perhaps telling me what they assumed I would 'want to hear,' yet the near unanimous chorus of support (Miller, 2016; Chamberlain, 2016) was tempered only by a few comments of nuance (Barclay, 2016; George, 2016) hardly changing the general tone of warm partnership, if not admiration.

Nevertheless, this partnership often proved to be onesided and fostered a culture that was already developing in Liberia since its civil war a decade prior: that if any development was to get done, some other country would have to do it (Mitchell, 2016; Miller, 2016; Hernandez, 2016). Often this notion was fostered by concerns of potential corruption in the Sirleaf administration (Interview, 2016; Hernandez, 2016), but also pragmatic experiences of induced dependency by Liberia's international partners (Selbach-Allen, 2016). While US PRTs were not utilized in Liberia, similar units comprised the US presence before and during the Ebola crisis. 
PRTs combine military and civilian leaders to engage with local governments and societies in insecure regions, typically in Iraq and Afghanistan. Some consider that this mandate "should be viewed as the paradigmatic expression of the new security/development nexus that conflates insecurity and underdevelopment and understands modern interventions as being 'complex' and requiring the coordination of all elements of Northern intervention" (Christie, 2012: 54). This linkage of insecurity and underdevelopment is discussed at length by several scholars concerned with the nexus (Christie, 2012; Duffield, 2001; 2007).

While the act of 'civilianizing' military units warrants criticism by both military leaders concerned with sanctity and identity of their profession as well as humanitarian workers concerned with theirs (Christie, 2012), the melding which results in the PRT structure has holistic benefits for an image of the military that is not all violent one that is keen to win over the 'hearts and minds' of the local population. For the context of Afghanistan, Christie cites a US Army PRT commander who praises the nuanced semi-civilian experience that national guardsmen brought to the operation rather than the traditional soldier, one that was able to more easily coalesce with local civilians (Ibid., p. 61). In Liberia, a non-PRT outfit which has been in existence since after the Liberian civil war, $\mathrm{OOL}$ takes on a similar tone. Between active-duty Marines (Selbach-Allen, 2016) and their transition to national guardsmen (Potter, 2016), a small group of US forces have been living alongside Liberian forces for years, building a relationship that stretches far beyond a quick-reaction surge of trust when a crisis pops up. The $\mathrm{OOL}$ chief of staff during the Ebola crisis was Colonel Stephen Potter, a Michigan Army National Guard senior officer who was part of the first national guard team to take over the mission after the Marine Corps' stint of leading.

He explained that he took an approach that was focused on trust rather than short-term success. "In the charts in Afghanistan and Iraq, you really needed to get to the finish line you needed to get from 'red' to 'green.' The key [in Liberia] was having trust in order to gain access and stability. You didn't need 'green' charts" (Potter, 2016). Rather than checking off lists of objectives right away the notion of 'getting to green' the OOL mission benefitted from its staying power and relative lack of surging since its inception in 2010 (Rankin, 2015). UNMIL has benefitted from its staying power 13 years long thus, far at time of writing and the trust that comes from that presence. While many organizations and diplomatic posts fled during the Ebola crisis, UNMIL hunkered down and did the best they could to maintain a presence despite fear and real danger from the disease. As a result, Liberian government and society have made the country one of the few countries where the UN is truly welcomed, unlike many others such as South Sudan
(Vrey, 2016).

\section{Implications for the US militarization of aid trend and the road ahead}

The predominant theoretical concern of this piece is militarization of aid and its consequences. When militaries start to be used more and more often instead of being used as a last resort, government resources are channeled increasingly toward that military. This phenomenon often occurs as a result of fear of disaster (terrorism, strategic standoff, Ebola), and as a result, funding is funneled away from other increasingly lessable agencies (USAID, CDC, Public Health Service). As time goes on, that last resort mentality becomes reality the military truly is the only organization with the capacity to complete humanitarian disaster response. Thus, a militarization of aid trend emerges, and has emerged in the US government construct particularly since 9/11. Throughout the oral histories of many American interviewees, one may see a herculean team working together to end the Ebola crisis, embracing local partners and powering through lack of existing resources. Those diplomats, aid workers, military officers and enlisted, and doctors have dedicated their careers to counter-acting disaster and for many, the 2014 Ebola crisis was an apotheosis.

That well-meaning and hard-working narrative does not have to be mutually exclusive to an increasing concern that the very nature of 'disaster-response' tends toward a search for capacity capacity that is increasingly only found with Ospreys and $\mathrm{MH}-60$ s, uniforms and good funding. That search is exemplified well when one considers the three days between decisions by the White House to respond to the Ebola crisis with a 25-bed field hospital, then three days later to respond with up to 3,000 troops. Subsequently, the President requested a $\$ 6 \mathrm{bn}$ emergency response package that was harshly debated by lawmakers. In the end it was approved, with some jarring justification by the committee chairwoman: "It's sudden, It's urgent, It's unforeseen, and it's temporary" (Hansen, 2014). While most of that aid did not necessarily go to the DoD, there were hundreds of millions that funded OUA. Surprisingly, OOL is funded by the State Department, not the DoD (Miles, 2012), demonstrating how far-reaching military involvement can be it can even assume funds of another agency. Thus, one must consider the humanitarian considerations of militarization, but also the economic costs and the political trend it encourages.

Most of the militarization of aid discourse deals with the shared mandate of humanitarian organizations and the military in a warzone, or at least a location that is often less developed and more riddled with violence. In this Ebola crisis context, the militarization of aid deals with 
concerns about conflating military capacity with what is societally accepted as a significant response (Obama moving from a field hospital to a 3,000 troop response due to external pressure). Secondly, it concerns the US military continuing a trend of being the best funded and equipped organization (the only organization with airlift capacity to get to remote areas in Liberia). Thirdly, the discourse considers a social movement in Liberia growing since the mid 1900s which demonstrates US partnership as military-first. The military influence in aid began in World War II for rubber extraction for materiel, continued in the Cold War for basing and force build-up, and lasted through the end of the Liberian civil war and Taylor's rule for an agreement of resignation. Most recently, the US' militarization of aid of Liberia took form once again in the Ebola crisis for construction and medical tasks. Starting well before the Ebola crisis, the US-Liberian relationship has tended towards a militarization of humanitarian aid and it became a logical conclusion in 2014, even when the mission was inherently non-violent.

Many Liberians know that corruption occurs and are trying to tell anyone of consequence who will listen, including Obama's daughters during their visit with the First Lady in June (Kollie, 2016). There are significant problems of ETU workers not getting their bonuses (Barclay, 2016), despite confirmations that the money was indeed dispatched, often by the US for the Liberian government to disperse (Paskman, 2016; Chamberlain, 2016). In the Liberian context, Jennings (2007), has criticized the underpinnings of the security-development nexus that securitization of a space will lead to its ability to develop. She argues that Demobilization, Disarmament, and Reintegration (DDR) processes in postcivil war Liberia have not led to a corresponding increase in development outcomes, particularly for ex-combatants. Denny argues a similar mantra for neighboring Sierra Leone that the British efforts to conduct SSR and professionalize the Sierra Leonean government have been largely met without less poverty or healthier people (2011). Much can be learned from these critiques, as time will tell whether the intervention by the US will suffer a similar fate to Britain's 'best' intervention in recent institutional memory in Sierra Leone (Albrecht and Jackson, 2014). Furthermore, the Ebola response in Sierra Leone by the UK has not come without critique about quick action and lack of planning (Haenlein and Godwin, 2015), although, there are some lessons to be learned about how the UK was able to achieve a balance that did not overpower local institutions, a notion that will be brought up in the conclusion of this piece.

The appropriateness and timing of aid in post-conflict settings (Collier and Hoeffler, 2004) as well as in the midst of health crises (Leach, 2015) is imperative to get right, lest it be deeply unproductive and damaging especially in the health environment. This 'appropriateness problem' comes across in the Sustainable Development Goals and the notion that development and change comes when people "realize well-being and justice in terms that make sense to them" rather than the "preaching messages that 'Ebola is Real,' adorning banners on the rainy streets of Monrovia, smack[ing] of distant authority" (Leach, 2015: 828-830). Nevertheless, the flooding of aid resulted in the bottom line of Ebola eradication, but it also resulted in national and international disputes of corruption and handling of the associated funds once they reached Liberian government administrators of all levels.

\section{CONCLUSION}

The Ebola crisis was a crushing epidemic for Liberia and the region, and it stopped there in part due to the international community's fear of the disease reaching its own communities and that fear mobilizing a massive response led by the US military. Now that the dust has settled, bodies have been buried or burned, and the nation is returning to a status quo, this piece serves to analyze the effects of that response through the lens of militarization of aid.

\section{A self-fulfilling prophesy}

By analyzing interviews and oral histories of a range of foreign officials, Liberian doctors and nurses, and corroboration from documentary analysis, this piece concludes that while the US played a role in stopping the spread of a violent disease, it continued along a historical and cultural path of militarization of aid. The consequences of that trend resulted in a costly and confusing choice to send a combat-oriented military unit to build physical structures when the military has specific construction forces for that mission and a host nation full of capable builders, not to mention humanitarian sectors of government charged with mandates for aid and health. Strategic level US leaders continued a self-fulfilling prophesy that the military is the only arm of government with enough funding and physical capacity to respond to crises. Liberian trust continued to be vested in external especially uniformed actors instead of local institutions to provide healthcare and security, deteriorating trust in local government and its components. Corruption ensued with little accountability by Liberian government, enshrouded by the nobility of ridding the nation from disease. The crisis' jargon calling it an international crisis encouraged both weighty and hasty action which was later considered to be ill advised.

\section{What's the balance?}

One of the most sizable issues in the US intervention was 
the choice of sending a combat-oriented military unit for a construction and health mission. The official line was that this unit was the only one capable and available, yet that decision had unforeseen effects, especially regarding the perception for NGOs on the ground. The militarized posture could have wrongly suggested for some that the choice was not about readiness but rather as a contingency for violent flare ups. While not intended, this posture undermined the local agency of the AFL, which has been working diligently to assume authority and respect after the nation's civil war ended hardly a decade prior to the Ebola crisis. Additionally, the US' actions facilitated a trend of dependency during a unique moment where that trend could have been changed. A combatoriented military unit may not have been the necessary fit for this crisis, particularly for physical building Liberian contractors did most of the construction of ETUs after all. Another concern is that the US responded to the Ebola crisis with troops because of media pressure. This suggests that a small number of specialized experts may not have constituted a publically accepted response, which is a serious problem for real-time efficacy of aid. Where then is the balance for military capacity in the Ebola crisis? Perhaps a place to look is the UK's intervention in Sierra Leone during the same crisis. The UK provided aid in a less generally militarized and more specialized manner. There were crisis specialists deployed on a British hospital ship, predominantly consisting of medical personnel and engineers whose utmost focus was on Sierra Leonean agencies' requests. Thus, this alternative UK approach tended towards partnership with local institutions and it benefitted from existing relationships, not a surge of command and control.

There is a unique power in small scale enduring relationships. They do not only save money in times of crisis, but when done well, they allow for influence that is balanced. Surges in aid can often lead to surges in power relations. With an influx in American funds and uniforms, there were skewed lines of trust for Liberians did US troops providing relief or did Liberian government? This article encourages alternative partnerships that are more cooperative like OOL (the small scale US-Liberians security sector reform mission) rather than mostly singlesided interventions as was seen with OUA (the large scale introduction of combat-oriented troops). With enduring relationships, local citizens can point to their own local institutions which coordinated responses for day to day operations as well as crises a necessary development particularly for a post conflict state where authority is not inherently accepted. More small scale, "left of bang," operations like OOL, combined with a strategy similar to the UK's specialized approach is a reasonable path forward. This article encourages policy makers and practitioners to move away from crisisoriented domination of a space and towards legitimate partnership that has value even when there's no war, no crisis, no rampant contagion. While one must not assume that that contagions can be eliminated by waiting and doing so on the cheap, this piece aims to reveal the issues with washing one's hands for the last time and calling the US response to the Ebola crisis an outright success worth emulating in the future, there must be a balance.

\section{Conflict of Interests}

The author is a member of the U.S. Military. This article does not necessarily represent the views of the U.S. government or its departments. With regard to the interviewees, it is imperative to note that the opinions expressed in either quotations or approximations are explicitly personal opinions and do not necessarily represent U.S. government positions or policies, the official positions or policies of the UN, nor the respective organizations for which other interviewees may work.

\section{REFERENCES}

Albrecht P, Jackson P (2014). Securing Sierra Leone: Introduction. Whitehall Papers. 82(1):1-18.

Arie S (2014, October 10). Only the military can get the Ebola epidemic under control: MSF head. BMJ. 1-3.

Barclay J (2016, June 13). In-person interview with an Ebola Treatment Unit worker. (D. Calcagno, Interviewer) Monrovia, Liberia.

Chamberlain $J(2016$, June 15). In-person interview with the US Embassy Political Officer. (D. Calcagno, Interviewer) Monrovia, Liberia.

Chan M (2014). WHO Director-General's speech to the Regional Committee for the Western Pacific. Manila: World Health Organization.

Cheng-zhong $L$ (2015). Thinking After Fighting Against the 2014 Ebola Epidemic in Liberia. Chin. Acad. J. Second Mil. Med. University. 36(6):581-583.

Christie R (2012, February). The Pacification of Soldiering, and the Militarization of Development: Contradictions Inherent in Provincial Reconstruction in Afghanistan. Globalizations. 9(1):53-71.

Ciment J (2013). Another America: The Story of Liberia and the Former Slaves Who Ruled It. New York: Hill and Wang.

Collier P, Hoeffler A (2002). Aid, Policy, and Peace: Reducing the Risks of Civil Conflict. Defence and Peace Economics. 13(6): 435-450.

Collier P, Hoeffler A (2004). Aid, Policy and Growth in Post-Conflict Societies. Eur. Econ. Rev. 48:1125-1145.

Cook P (2016). Statement by Pentagon Press Secretary Peter Cook on U.S. Airstrike in Somalia. Retrieved August 6, 2016, from U.S. Department of Defense, June 1: http://www.defense.gov/News/NewsReleases/News-Release-View/Article/788062/statement-bypentagon-press-secretary-peter-cook-on-us-airstrike-in-somalia

Cooper H, Shear M, Grady D (2014, September 15). U.S. to Commit Up to 3,000 Troops to Fight Ebola in Africa. New York Times. pp. 1-4.

Cronk TM (2014, September 12). DOD to Send 25-bed Hospital to Liberia in Fight Against Ebola Virus. Retrieved July 19, 2016, from U.S. Department of Defense: http://www.defense.gov/News-ArticleView/Article/603234/dod-to-send-25-bed-hospital-to-liberia-in-fightagainst-ebola-virus.

Denney L (2011). Reducing Poverty with Teargas and Batons: The Security Development Nexus in Sierra Leone, February 18. Afr. Aff. 110(439):275-294. 
Diehl P, Druckman D, Wall J (1998). International Peacekeeping and Conflict Resolution. J. Confl. Resolut. 42(1):34.

DoD (2015). DoD Helps Fight Ebola in Liberia and West Africa. Retrieved July 14, 2016, from U.S. Department of Defense: http://archive.defense.gov/home/features/2014/1014_ebola/

Dube O, Naidu S (2014). Bases, Bullets and Ballots: the Effect of U.S. Military Aid on Political Conflict in Colombia. Cambridge, Mass: Nat. Bur. Econ. Res.

Duffield M (2001). Global Governance and the New Wars: The Merging of Development and Security. London: Zed.

Duffield M (2007). Development, Security, and Unending War: Governing the World of Peoples. Cambridge: Polity Press.

Fetherston A (2000). Peacekeeping, conflict resolution and peacebuilding: A reconsideration of theoretical frameworks. Int. Peacekeeping. 7(1):190-218.

Gaye L, Hector H (2014, December 3). Healthcare workers on the frontline of Ebola: Louise's story. One. 1-2.

George J (2016, June 16). In-person interview with the Chief Medical Officer of the Armed Forces of Liberia. (D. Calcagno, Interviewer) Monrovia, Liberia.

Gibson A (2013, August 2). Seabees recognized for efforts across HOA. Retrieved July 16, 2016, from Combined Joint Task Force - Horn of Africa: http://www.hoa.africom.mil/story/7800/seabees-recognizedfor-efforts-across-hoa

Haenlein C, Godwin A (2015). Containing Ebola: A Test for PostConflict Security Sector Reform in Sierra Leone. Stability: Int. J. Secur. Dev. 4(1):38.

Hansen M (2014, November 12). Lawmakers question Obama's \$6billion request for Ebola funding. Los Angeles Times. 1-3.

Hernandez H (2016, June 23). In-person interview with the head of US Embassy security for over 20 years. (D. Calcagno, Interviewer) Monrovia, Liberia.

Hewitt K (2016). Disaster Risk Reduction in the Era of "Homeland Security": The Struggle for Precautionary, Preventive, and Nonviolent Approaches. In K. Sudmeier-Rieux, M. Fernández, I. Penna, M. Jaboyedoff, \& J. Gaillard, Identifying Emerging Issues in Disaster Risk Reduction, Migration, Climate Change and Sustainable Development: 35-51. Lausanne, Switzerland: Springer.

Interview (2016, July 8). In-person interview with Liberian living in Congo Town. Monrovia, Liberia.

Jennings K (2007). The Struggle to Satisfy: DDR Through the Eyes of Ex-combatants in Liberia. Int. Peacekeeping. 14(2): 204-218.

Kim Y, Nunnenkamp P (2013). Does It Pay for US-based NGOs to Go to War? Empirical Evidence for Afghanistan and Iraq. Kiel, Germany: Kiel Institute for the World Economy.

Kollie M (2016, June 26). Letter To Malia And Sasha Obama - Weeping Voices In Dying Valleys. Daily Observer. 1-4.

Krahenbuhl P. (2011, February 22). The militarization of aid and its perils. ICRC. 1-2.

Kulish N, Schmitt E (2013, October 8). 'Imperfect Intelligence' Said to Hinder U.S. Raid on Militant in Somalia. The New York Times. 1-5.

Lane J, McNair S (2015). Sending Soldiers to Fight Ebola. Military Medicine. 180(6): 607-608.

Leach M (2015). The Ebola Crisis and Post-2015 Development. J. Intl. Dev. 27: 816-834.

Miles D (2012, June 26). Signs of Military Professionalism, Cooperation On Rise in Africa. Retrieved July 23, 2016, from U.S. Department of Defense: $t p: / / a r c h i v e . d e f e n s e . g o v /$ news/newsarticle.aspx?id=116903

Miller M (2016, June 15). In-person interview with US military officer. (D. Calcagno, Interviewer) Monrovia, Liberia.

Mitchell D (2015). Blurred Lines? Provincial Reconstruction Teams and NGO Insecurity in Afghanistan, 2010-2011. Stability: Intl J. Security Dev. 4(1): Art. 9.

Mitchell T (2016). Phone interview with the US Senior Defense Official in Liberia during the Ebola outbreak, June 22. (D. Calcagno, Interviewer).
Parham R, Wanjue C (2016). In-person interview with representatives of the Office of US Foreign Disaster Assistance (OFDA). (D. Calcagno, Interviewer) Monrovia, Liberia, June 15.

Paskman S (2016). In-person interview with the acting US Ambassador to Liberia. (D. Calcagno, Interviewer) Monrovia, Liberia, June 15.

PBS (2002). Liberia: America's Stepchild [Motion Picture].

Phillip A (2014). Eight dead in attack on Ebola team in Guinea. 'Killed in cold blood.' , September 18. The Washington Post. 1-2.

Potter S (2016, June 23). Phone interview with the Officer in Charge of the US Operation Onward Liberty in Liberia during the Ebola outbreak. (D. Calcagno, Interviewer).

Rankin D (2015). Michigan National Guard continues mentor-mission to Liberian armed forces. Retrieved July 9, 2016, from Michigan National Guard: http://minationalguard.com/michigan-national-guardcontinues-mentor-mission-to-liberian-armed-forces/

Selbach-Allen M (2016). Phone interview with a US Marine Officer serving in Liberia during the height of the Ebola outbreak. (D. Calcagno, Interviewer) June 09.

Selbach-Allen M (2016b). Follow-Up Interview Correspondence with US Marine Corps Officer Serving in Liberia During the Height of the Ebola Crisis. (D. Calcagno, Interviewer), July 19.

Simeone N (2015). U.S. Conducts Counterterrorism Operation in Somalia. Retrieved August 6, 2016, from U.S. Department of Defense March 13 http://www.defense.gov/News/Article/Article/604274

Soyombo F (2016). The plunder of West Africa Ebola funds. Al Jazeera. 1-14.

Spearie S (2016). Nurse helped in fight against Ebola. The State Journal-Register, July 3, January 29. 1-4.

Stack J, Brabazon J (2004). Liberia: An Uncivil War [Motion Picture]. United States of America.

UNMIL Official 1 (2016). In-person interview with an UNMIL official. (D. Calcagno, Interviewer) Monrovia, Liberia, July 8.

UNMIL Official 2 (2016). In-person interview with an UNMIL official. (D. Calcagno, Interviewer) Monrovia, Liberia, July 8.

USAID (2016). Ebola: Get the Facts - The United States has done more than any other country to help West Africa respond to the Ebola crisis. Retrieved July 14, 2016, from United States Agency for International Development: https://www.usaid.gov/ebola/facts

USAID (2016b). USAID/OFDA Support for Liberia's Ebola Response. Washington, D.C.: US Agency for International Development.

Vrey W (2016, July 8). In-person interview with the UNMIL Deputy Special Representative of the Secretary General for Rule of Law. (D. Calcagno, Interviewer) Monrovia, Liberia.

Waugh C (2011). Charles Taylor and Liberia: Ambition and Atrocity in Africa's Lone Star State. London: Zed.

Weissman F (2004). Military Humanitarianism: A Deadly Confusion. Paris: Médecins Sans Frontières.

White D (2014, September 30). Seabees from Task Force 68 to support Ebola Outbreak Response. Retrieved July 16, 2016, from Combined Joint Task Force - Horn of Africa: http://www.hoa.africom.mil/story/8428/seabees-from-task-force-68-tosupport-ebola-outbreak-response

WHO (2014). Statement on the 1st meeting of the IHR Emergency Committee on the 2014 Ebola outbreak in West Africa. Media Centre. Geneva: World Health Organization.

WHO (2016). Ebola Situation Report - 17 February 2016. Geneva: World Health Organization.

WHO (2016b). Latest Ebola outbreak over in Liberia; West Africa is at zero, but new flare-ups are likely to occur. Media Centre. Monrovia: World Health Organization. 